\title{
The Effects of Technical and Fundamental Factors on the Investment Decision and the Company Value in the Agricultural Sector
}

\author{
Mamay Komarudin* \& Naufal Affandi \\ Faculty of Economics and Business, Bina Bangsa University, Serang, Indonesia
}

\begin{abstract}
This study aims to analyze the influences of technical variables, which consist of the stock price and the Total Volume Activity (TVA), as well as fundamental variables, which consist of the Price Book Value (PBV) and the Debt to Equity Ratio (DER) on the investment decisions and the company value measured by using the PER of some companies of agricultural sector listed in the Indonesian Stock Exchange. Path analysis is used as the data analysis method. The research results show that one of the technical factors that significantly influence the investment decision and the company value is the stock price. Meanwhile, one of the fundamental factors that influence the investment decision and the company value is the PBV. The hypothesis testing showing that the stock price factor and the PBV factor have positive effects on the value of the agricultural sector company is proven or accepted. On the other hand, the other variables, according to theorems trimming, are proved to be not includable in the path calculation if the path is proved to be insignificant, in this case, the DER, and the trading volume variable
\end{abstract}

Keywords: DER, stock price, company value, investment decisions, TVA, PBV

\section{Introduction}

As a large agrarian country, Indonesia certainly has significant economic opportunities, especially in the agrarian sector. It is called an agrarian country because more than $40 \%$ of the Indonesian population either directly or indirectly, depend their lives on the agricultural sector. Therefore, the agricultural sector plays an important role in the national economy. This agricultural sector will face regulatory challenges from export destination countries that require eco-green in the future. The regulation will certainly affect the way of production, the amount of production which ultimately affects the need for investment capital and working capital, besides that the regulation will also certainly change investors' perceptions of agricultural sector shares and this of course must be explored through research, Besides that, there is also a tendency for an increase in the PBV in the agricultural sector during 2010-2014.

This sector also becomes a primary sector for many other sectors. It is simply because the products produced by the agricultural sector are also needed by the other sectors. Considering this condition, the agricultural sector certainly provides more opportunities for investors to make their investments through the capital market.

Capital market is one of investment media that connects the investors, the party who have funds and hopes of gaining profit, with the companies, the party who are in need of capital for development.

Investors certainly expect maximum financial profit of their investment shares. That is why they, including those investing in the Indonesian Stock Exchange (BEI), will choose companies with great future prospects. To view the companies' prospects, the investors can do it by assessing their stock value. Recently, assessing and investing in the agricultural sector seems to be very promising.

Despite being profitable and interesting, stock investment is also classified as a high risk investment. Public company share is highly sensitive to changes, either good or bad, due to changes in politics, economics, and monetary in

\footnotetext{
${ }^{*}$ Corresponding author.

E-mail address: mamaykomarudin2014@gmail.com (Mamay Komarudin)
} 
foreign or domestic scope. Such changes can have a positive impact which means increasing the stock exchange, or a negative one which leads to the contrasting result. For that reason, in stock investment, an investor should conduct an analysis of factors that may affect a company, in order to minimize losses that could arise from the fluctuation in the growth and the development of the company in concern. In analyzing and selecting the stocks, there are two aspects or approaches that are often used, namely fundamental aspects and the technical aspects.

Investment plays a role in the growth of agricultural sector companies where it cannot be separated from the role of private and government investment. The role of private investment in the capital market is reflected in the total capitalization of shares in the agricultural sector, which needs to be closely monitored by the capitalization of shares in the agricultural sector, which is an indicator of the growth of company shares in the capital market. An owner of capital must have an effective investment plan in order to gain profits in the capital market. One form of investment that fund owners make is buying shares in the hope of obtaining the most optimal return, either dividends or capital gains. The existence of benefits can increase the value of the company. Maximizing firm value is very important for a company, because maximizing firm value also means maximizing the prosperity of shareholders, which is the main goal of the company (Martono and Harjito, 2013: 13). Firms that consistently generate higher returns to their owners of capital than they can in alternative investment opportunities are rewarded with a higher market value. A company's market value can fluctuate over time in response to many factors that can be difficult or impossible to predict.

There are several factors related to company value. One of them is an investment decision made by the company. Firm value is the owner's perception of the company's success rate which is often associated with investment decisions. Companies carrying out investment activities are the most difficult decisions for company management because they will affect the value of the company (Vranakis and Prodmoros, 2014). The purpose of making an investment decision is to get a large return with manageable risk in the hope that it can optimize company value.

The investment decision of the owner of capital is measured by the value of the investment invested in agricultural sector companies. Investment decisions are related to firm value. Hajering (2018), Tong and Reuer (2017), Handriani and Robiyanto (2018), and Yulia (2017) examine investment decisions where the results show that investment decisions have a significant effect on firm value. The existence of higher investment from the company will also make the company value even higher. However, these results are not supported by research conducted by Lee and Wang (2017) which states that investment decisions do not have a negative effect on firm value. Lee and Wang (2017), Boumosleh (2012), Murniati et al. (2019) which states that investment decisions have no effect on firm value.

There are several factors that affect the fluctuation of company value, one of which is fundamental factors and technical factors. Fundamental factors have a significant effect on firm value. Fundamental factors as measured by financial performance can increase company value. Cheung et al. (2015) and Drakopoulou (2015) state that fundamental factor indicators have a significant effect on firm value. Meanwhile, Kodongo et.al (2014) found that financial ratios as a fundamental basis have no significant effect on firm value.

Technical analysis is an analysis of stocks that must be carried out carefully, especially regarding the level of return and risk. With the analysis, it is hoped that it can be used as a basis for decision making. The right decision will give optimal results. Tapa and Hussin (2016), Cheung (2015). Hussain (2019), Pathirawasam (2019), Yahyazadehfar (2014), Lee et al. 2018), Chipunza (2017) and Yulia (2017) found that technical factors have a significant effect on stock value. Meanwhile, Tapa and Hussin (2016), Drakopoulou (2015) found that technical factors did not significantly influence firm value.

Firm value can provide maximum prosperity for shareholders if the company's share price increases. The higher the share price, the higher the shareholder's wealth. To achieve company value, investors generally leave their management to professionals. Sabrin et.al (2016) stated that technical factors as measured by stock prices have a positive effect on firm value. Hussain et al. (2019), Lee et al. (2018), Chipunza et al. (2017) and Drakopoulou (2015) found that stock prices have a positive effect on firm value. Tapa and Hussin (2016), Cheung et al. 2015) and Ahmadi (2018) found that stock prices have no significant effect on firm value.

Investment decisions are related to the company's technical and fundamentals. Fundamental factors relate to investment decisions in relation to financial performance measures. Fundamental factors that are measured by the analysis of financial ratios that are carried out will provide information about the financial condition and financial 
performance of a company which is the basis for the decisions of the owners of capital in making decisions to invest. Baresa and Ivanovic (2016), Maulina et al. (2018) and Yulia (2017) found that fundamental factors significantly influence investment decisions. Meanwhile, Muhammad and Ali (2018), Fernandes and Tomé (2017), Mondosha and Majoni (2017), Sajid et al. (2016) and Sajid et al. (2016) found that fundamental factors do not significantly influence investment decisions.

Meanwhile, technical factors are studies conducted to study the various forces that influence the stock market and their implications for stock prices. Suresh (2013) who examines the economic environment, industrial performance and company performance before making investment decisions. The research found that fundamental and technical factors are tools for valuation before deciding on stock investment. Seetharaman et al. (2017), Risman et al. (2017), Masry (2017) and Hussain et al. (2019) explain that technical factors have a significant effect on investment decisions. Meanwhile, Muhammad and Ali (2018) explain that technical factors do not have a significant effect on investment decisions.

An analysis of shares must be carefully conducted, especially regarding the level of return and risk. The analysis is expected to be the basis of decision making. The right decision will be able to provide an optimal result. Investors will be able to know stocks from many different sectors. If we look further, the stock performance of agribusiness in the stock market shows a rapid growth. This is shown by the indexical movement graphic of the agricultural sector, which is higher on the stock exchange, compared to other sectors or to the IDX composite movement in the same period of time (Sugiartawan et al, 2013). Agribusiness companies are likely to produce greater returns than other companies or other issuers, so that investment eligibility in the agricultural sector, especially in the form of shares, will affect the generated investment returns.

The agricultural sector contributes $25.7 \%$ toward the company value in Indonesia's trade balance in 2008 until 2013 (http://agriwarta.fp.ub.ac.id). It is also noted that in 2013, the total export of agricultural products reached 23.89 million tons that was valued at US\$22.2 billion (http://www.antaranews.com). The following table shows the share price development in agricultural sector in 2009-2013.

Table 1. The Average Stock Price of Agriculture (in IDR) (Years 2009-2013)

\begin{tabular}{ccccccc}
\hline \multirow{2}{*}{ No. } & \multirow{2}{*}{ Sector } & \multicolumn{5}{c}{ Years } \\
\cline { 3 - 6 } & & 2009 & 2010 & 2011 & 2012 & 2013 \\
\hline 1 & Agriculture & $1,913.647$ & $2,344.557$ & $2,456.066$ & $2,248.026$ & $2,139.96$ \\
\hline
\end{tabular}

Source: www.idx.co.id (processed)

Table 1 shows that the average stock price of agriculture sector fluctuated from 2009 to 2013 . Table 1 also shows that agriculture sector decreased consistently for over the last five years. Although agricultural sector experienced a decline in stock price, agricultural sector is important for the Indonesian economy.

Based on this background, this study aims to analyze the influence of technical variables, which consists of shares and Total Volume Activity (TVA), and the fundamental variables which consist of Price Book Value (PBV) and Debt to Equity Ratio (DER), on the investment decisions and the company value in the agricultural sector, which is listed in the Indonesia Stock Exchange.

\section{Theoretical Framework and Hypothesis}

a. Value of Firm Theory

Firm value is the owner's perception of the company's success rate which is often associated with the stock price. High stock prices, the company value is also high and automatically the company returns will be high. Maximizing the prosperity of shareholders can translate into maximizing the company's share price. Although the company has other goals, maximizing the share price is the most important goal (Brigham and Houston, 2013).

The theory that underlies this company value is the theory of corporate stakeholders not only being responsible for the shareholders, but shifting to the social realm, hereinafter referred to as social responsibility. This kind of 
phenomenon occurs due to demands from society as a result of the negative externalities that arise and social inequalities that occur.

\section{b. Signaling Theory}

Signaling theory is a theory that discusses the ups and downs of prices in the market such as stock prices, bonds and so on, so that they will influence the decisions of the owners of capital. The response of investors to positive and negative signals is that they greatly affect market conditions, they will react in various ways in response to these signals, such as hunting for stocks that are sold or taking actions in the form of not reacting such as "wait and see" or wait and see developments then take action. The decision to wait and see is not something that is bad or wrong, but it is seen as a reaction by the owner of the capital to avoid the emergence of a greater risk due to market factors that have not benefited or taken his side (Fahmi, 2014: 21).

\section{c. Hypothesis Development}

The hypothesis formulated in this study is that defined variables have an influence on the value of agricultural enterprises.

\section{Effect of Stock Prices on Investment Decisions}

The stock price that is formed in the market already reflects all available information. The factors of interest rate, ownership concentration, company size, profitability, RUPS, growth and other do not need to be analyzed quantitatively. This has been reflected in the formation of prices. The share price is more of a function of the demand and supply of shares. Stock prices that are formed individually or as a whole in the market tend to move in the direction of the trend over a relatively long period of time. There is a price pattern repeating itself in the future. Patterns of stock price movements based on observations of past price movements are contrary to the efficient market hypothesis, namely that past stock performance will not affect stock performance in the future. Wang et al. (2016), Hussain (2019) and Boumosleh (2012) found that stock prices have a significant effect on investment decisions. Based on this description, the research hypothesis is as follows.

\section{H1: Stock prices have a positive and significant effect on investment decisions}

\section{The Effect of Stock Trading Volume on Investment Decisions}

The total volume of share price activity is determined by supply and demand. This approach emphasizes the importance of the behavior of capital owners in the future and based on the past, so that the analysis studies stock price changes using historical trading data. Technical factors can be done by valuing stocks using statistical data generated from stock trading activities such as stock prices, trading volume, demand and supply of certain shares and the market as a whole. Ruhani and Quddus (2018), Masry (2017) and Hussain et al. 2019) found that trading volume has a positive and significant effect on investment decisions. Based on this description, the research hypothesis is as follows.

\section{H2: Stock trading volume has a positive and significant effect on investment decisions}

\section{The Effect of PBV on Investment Decisions}

PBV is a market value that influences investment decisions. Due to uncertainty in the future, the benefits are uncertain, so that the investment proposal carries risks. The decision to allocate capital to investment proposals must be evaluated and linked to the risks and expected returns. Thus it can be concluded that when investing, the company is able to generate profits by using company resources efficiently, then the company will gain the trust of prospective owners of capital to buy shares. Thus, the higher the company's profits, the higher the firm value, which means the greater the prosperity the company will receive. Based on this description, the research hypothesis is as follows.

\section{H3: PBV has a positive and significant effect on investment decisions}

\section{The Effect of Debt To Equity Ratio on Investment Decisions}


Based on the opinion of Martono and Harjito (2013: 81) it refers to the use of assets and sources of funds by companies where in using these assets or funds the company must pay fixed costs or fixed expenses. The solvency ratio or Leverage is the ratio used to measure the extent to which the company's assets are financed with debt. This means how much debt burden the company bears compared to its assets (Kasmir, 2008: 151). Maulina et al. (2018) and Yulia (2017) found that leverage has a positive and significant effect on investment decisions. Meanwhile, Fernandes and Tomé (2017), Mondosha and Majoni and Sajid et al. (2016) has a negative and significant effect on investment decisions. Based on this description, the research hypothesis is as follows.

\section{H4: Debt to Equity Ratio has a positive and significant effect on investment decisions}

\section{The Effect of Share Prices on Firm Value}

Hussain et al. (2019), Chipunza et al. (2017) and Drakopoulou (2015) explain that stock prices can have a positive and significant effect on firm value. Firm value is the owner's perception of the company's success rate which is often associated with the stock price. The high stock price makes the company value high. A high company value will make the market believe not only in the company's current performance but also in the company's future prospects. Based on this description, the research hypothesis is as follows.

\section{H5: Stock prices have a positive and significant effect on firm value}

\section{The Effect of Stock Trading Volume on Firm Value}

The trading volume of a share price is determined by supply and demand. This approach emphasizes the importance of the behavior of capital owners in the future and based on the past, so that the analysis studies stock price changes using historical trading data. Technical factors can be done by valuing stocks using statistical data generated from stock trading activities such as stock prices, trading volume, demand and supply of certain shares and the market as a whole. Zulkarnaen et al. 2016), Hussain et al. 2019), Pathirawasam (2019) and Chipunza et al. (2017) found that trading volume has a significant effect on firm value. Based on this description, the research hypothesis is as follows.

H6: Debt to Equity Ratio has a positive and significant effect on firm value

\section{The Effect of PBV on Firm Value}

The Price to Book Value ratio describes the value of the company. The value of the company can be seen from its share price, because the stock price reflects the company's performance. The greater the PBV, the higher the company value. The use of PBV indicators is based on research by Fama (1978) who in his research used the concept of market value to measure firm value. The market value is the value formed by the supply and demand for shares by market participants in investing. Based on this description, the research hypothesis is as follows.

H7: Debt to Equity Ratio has a positive and significant effect on firm value

\section{Effect of Debt To Equity Ratio on Firm Value}

Based on the opinion of Harahap (2013: 2), Leverage is a ratio that describes the relationship between company debt to capital, this ratio can see how far the company is financed by debt or external parties with the company's ability as described by capital. According to Fahmi (2012: 2) Leverage is a measure used in analyzing financial statements to show the amount of collateral available to creditors. This study found the Leverage ratio is measured by DER (Debt to equity ratio).

Based on the opinion of Brigham and Houston (2015), a high DER will show a large debt value, with a large debt, where the debt can be used as capital to turn the company's activities for profit which will increase the company's value. Empirical evidence with the results of research by Chen and Yu (2011), Cheng and Tzeng (2011), Zuhroh (2019), Jeleel and Olayiwola (2017), Farooq and Masood (2016), Djamaluddin et al. (2018), Ramadan (2015), Hussain et al. (2019), Balakrishnan and Ramachandran (2016) which state that the leverage ratio has a positive and significant effect on firm value. Based on this description, the following hypothesis is explained. 


\section{H8: Debt to Equity Ratio has a positive and significant effect on firm value}

\section{The Effect of Investment Decisions on Firm Value}

Investment decisions are a matter of how financial managers must allocate funds into investment forms that will be able to bring benefits in the future (Sutrisno, 2012: 5). Investment decisions are the most important of the two other policies in financial management, namely funding decisions and dividend policies. Capital investment is the main aspect of financial management policy because investment is a form of capital allocation whose realization must produce benefits or gains in the future.

Investment decisions are an important factor in the company's financial function. Fama (1978) in Susanti (2010) states that firm value is determined solely by investment decisions. This opinion can be interpreted that investment decisions are important, because to achieve company goals can be achieved through company investment activities. Investment decisions are related to firm value. Hajering (2018), Ahmad and Siahaan (2016), Tong and Reuer (2017), Handriani and Robiyanto (2018), Rasyid et al. (2014), Lee et al. (2018), Silva et al. (2017) and Yulia (2017 found that investment decisions have a significant effect on firm value. To achieve the goal of increasing firm value, a manager is needed who is able to make the right financial decisions. One of the financial decisions that must be taken by a manager is an investment decision. The higher the investment from the company, the higher the firm's value.Based on empirical and theoretical descriptions, the following hypotheses can be formulated:

H9 = investment decision has a positive and significant effect on firm value

\section{Research Methodology}

The study was conducted by collecting the secondary data from 22 companies in the agricultural sector whose shares are listed on the Indonesia Stock Exchange, which consists of three sectors namely: plantations, fisheries, and other agricultural sectors as listed in table 2 .

Table 2. The List of Agricultural Sector Issuers in the Indonesia Stock Exchange (BEI) 2014

\begin{tabular}{lll}
\hline No. & Stock Code & Name of Issuer \\
\hline Plantation Sub-Sector & \\
\hline 1 & AALI & Astra Agro Lestari Tbk \\
2 & ANJT & Austindo Nusantara Jaya Tbk \\
3 & BWPT & Eagle High Plantations Tbk \\
4 & DSNG & Dharma Satya Nusantara Tbk \\
5 & GOLL & Golden Plantation Tbk \\
6 & GZCO & Gozco Plantations Tbk \\
7 & JAWA & Jaya Agra Wattie Tbk \\
8 & LSIP & PP London Sumatra Indonesia Tbk \\
9 & MAGP & Multi Agro Gemilang Plantation Tbk \\
10 & PALM & PT Provident Agro Tbk \\
11 & SGRO & Sampoerna Agro Tbk \\
12 & SIMP & Salim Ivomas Pratama Tbk \\
13 & SMAR & Smart Tbk \\
14 & SSMS & Sawit Sumbermas Sarana Tbk \\
15 & TBLA & Tunas Baru Lampung Tbk \\
\end{tabular}




\begin{tabular}{lll}
\hline No. & Stock Code & Name of Issuer \\
\hline 16 & UNSP & Bakrie Sumatra Plantations Tbk \\
\hline Fisheries Sub-Sector & \\
\hline 17 & CPRO & Central Proteina Prima Tbk \\
18 & DSFI & Dharma Samudera Fishing Industries Tbk \\
19 & IIKP & Inti Agri Resources Tbk \\
\hline Other Sectors & \\
\hline 20 & BISI & BISI International Tbk \\
21 & BTEK & Bumi Teknokultura Unggul Tbk \\
22 & CKRA & Cakra Mineral Tbk \\
\hline
\end{tabular}

One of sampling techniques included in non-random sampling is the purposive sampling. In this research, sampling was done by using an approach through purposive sampling method, where data is taken based on certain considerations, and the requirements made as the criteria need to be fulfilled by the sample in order to obtain a representative sample (Ende \& Kusuma, 2017).

The sampling was done by using purposive sampling method with the purpose to obtain a representative sample using the following criteria:

1. The agricultural companies in the plantation sector are listed in the Indonesia Stock Exchange and were active in doing transactions during 2010-2014 period.

2. The Companies completed their annual financial statements in the period of 2010-2014.

Based on the sampling criteria as mentioned above, the samples used in this study are 8 companies, as listed in table 2 below:

Table 2. Sampling Process Research

\begin{tabular}{llc}
\hline No. & Description & Company \\
\hline 1 & Agricultural companies listed in the Stock Exchange in 2014 & 22 \\
2 & Agricultural companies not consecutively registered in 2010-2014 & 16 \\
3 & Agricultural companies in the plantation sector listed in the Stock Exchange in 2014 & 16 \\
4 & Agricultural companies in the plantation sector listed in succession in 2010-2014 & 8 \\
5 & Companies completing annual financial statements in the period 2010-2014 & 8 \\
6 & Companies consistently presenting financial statements of each observation period, namely & 8 \\
7 & 2010-2014 & 8 \\
\hline
\end{tabular}

Source: The Indonesia Stock Exchange

Based on the process of sampling, there were 8 companies involved. The research was conducted during the period of 2010 to 2014. 


\subsection{The Research Design}

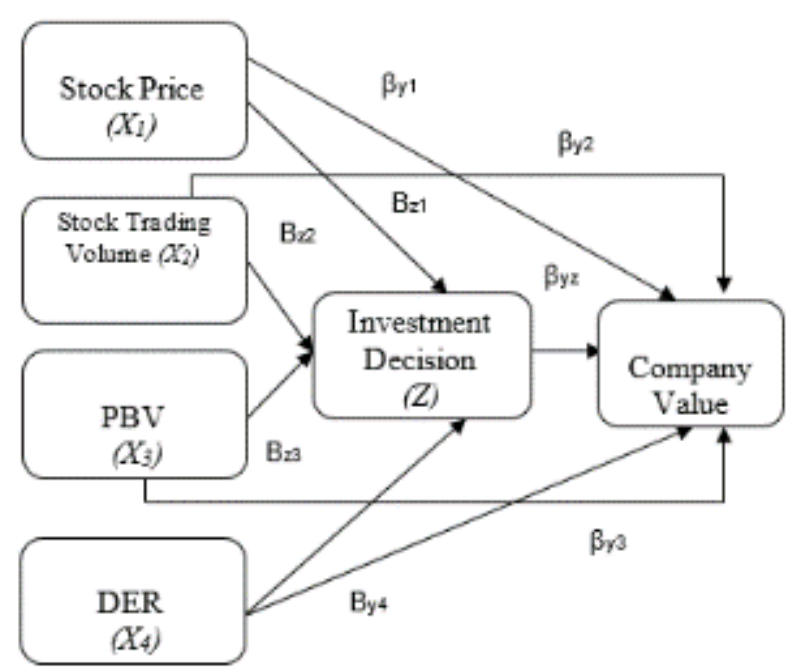

Fig. 1. Research Conceptual Framework

\subsection{Path Analysis}

Path Analysis is an analysis to determine the contribution of the effects of each variable $X$ and $Y$ that use standardized variables (Kusuma et al., 2020). By using path analysis, the causal effect between the variable and the position of each variable in the pathway, either directly or indirectly, will be estimated. The model significant appears based on beta coefficient $(\beta)$, which is significant to the path.

Based on the results, these coefficients can be described as follows.

$Z: \beta o=\beta z x 1+\beta z x 2+\beta z x 3+\beta z x 4+\varepsilon 1$

$Y: \beta o=\beta y x 1+\beta y x 2+\beta y x 3+\beta y x 4+\beta y z+\varepsilon 2$

where:

$Y=$ company value

$Z=$ investment decisions

$X_{1}=$ stock price

$X_{2}=$ stock trading volume

$X_{3}=$ PBV

$X_{4}=$ DER

$\beta 0=$ intercept

$\varepsilon 1.2=$ residual variable $/$ error

The result of the new structure are recalculated at each path coefficient. Based on the result, the direct and indirect effect, as well as the total effect, can be seen. The calculation step is to calculate the direct and indirect effects, as well as the influence of technical and fundamental factors toward the company value through intervening the investment decision variable $(Z)$ and then calculating the remaining residual variable, that is variables other than the independent variables and intermediate variables that also affect the dependent variables, but are not included in the research model. 


\section{Result and Discussion}

After obtaining a multiple linear regression model, the next step is to test whether the model developed is BLUE (Best Linear Unbiased Estimator). BLUE assumptions that must be addressed include: no multi-collinearity, homoscedasticity, and no autocorrelation. The classical assumption testing performed on the two linear regression models are described as follows:

\section{a. $\quad$ Normality Test Model}

A data normality test is performed to determine whether the model obtained has a normal distribution or not. The path analysis result model must meet the assumptions of normality conducted on the samples by using the chart plots described in Figure 1.

Table 5. Path Coefficient and Hypotheses Testing Value

\begin{tabular}{|c|c|c|c|c|c|}
\hline Hypothesis & $\begin{array}{l}\text { Free } \\
\text { Variable }\end{array}$ & $\begin{array}{l}\text { Bound } \\
\text { Variable }\end{array}$ & $\operatorname{Beta}(\beta)$ & t-calculation & $\rho$-value \\
\hline 1 & Stock Price $(X 1)$ & Investment Decision $(Z)$ & 0.265 & 2.175 & 0.048 \\
\hline 2 & Stock Trading Volume $(X 2)$ & Investment Decision $(Z)$ & 0.028 & 0.169 & 0.867 \\
\hline 3 & $\operatorname{PBV}(X 3)$ & Investment Decision $(Z)$ & 0.527 & 2.376 & 0.023 \\
\hline 4 & $\operatorname{DER}(X 4)$ & Investment Decision $(Z)$ & -0.015 & -0.089 & 0.930 \\
\hline 5 & Stock Price $(X 1)$ & Company Value $(Y)$ & 0.280 & 2.272 & 0.012 \\
\hline 6 & Stock Trading Volume $(X 2)$ & Company Value $(Y)$ & 0.050 & 0.296 & 0.769 \\
\hline 7 & $\operatorname{PBV}(X 3)$ & Company Value $(Y)$ & 0.566 & 2.606 & 0.013 \\
\hline 8 & $\operatorname{DER}(X 4)$ & Company Value $(Y)$ & -0.013 & -0.079 & 0.937 \\
\hline 9 & Investment Decision $(Z)$ & Company Value $(Y)$ & 0.265 & 2.686 & 0.010 \\
\hline
\end{tabular}

Source: Processed data

Note: $* *=$ Significant at $\alpha=5 \%$

Based on the result of the coefficient regression, the modeling can be described as follows.

$Z=0.265 X 1+0.028 X 2+0.527 X 3-0.015 X 4$

$Y=0.280 X 1+0.050 X 2+0.566 X 3-0.013 X 3+0.265 Z$

Fig. 1 shows that the model in regression is able to meet the normality assumption in the model. This is shown through the data spread which is around the diagonal line and follows the direction of the diagonal line, so that the model meets the normality assumption model.

\section{b. Multicollinearity Test}

One assumption underlying the linear regression model is the absence of a perfect linear relationship between some or all of the independent variables (Ariska et al., 2020). That means the regression model does not violate the assumption of no multicollinearity. The presence or absence of multicollinearity can be seen in the Variance Inflation Factor (VIF). Santoso (2000:234) stated that an indication of multicollinearity will not occur among the independent variables if the VIF is less than 5. The result of the multicollinearity in this study can be seen in table 6 .

According to table 6, there is no multicollinearity among the independent variables for VIF is less than 5. It means that there is not a perfect linear relationship between some or all of the independent variables.

1) Autocorrelation Test 
The purpose of this test is to determine whether in a linear regression, there is a correlation between the linear regression error in the period $t$ and the error in period $t-1$ (previously). If it happens, then there is a problem of autocorrelation in the regression model. The regression model must not violate the assumption of no autocorrelation. The presence of autocorrelation in the regression model can be detected by observing the magnitude of Durbin Watson (DW). If the DW coefficient is between -2 to +2 , then it means no autocorrelation (the investment decision $=$ 1.802 and the company value $=1.902$ ).

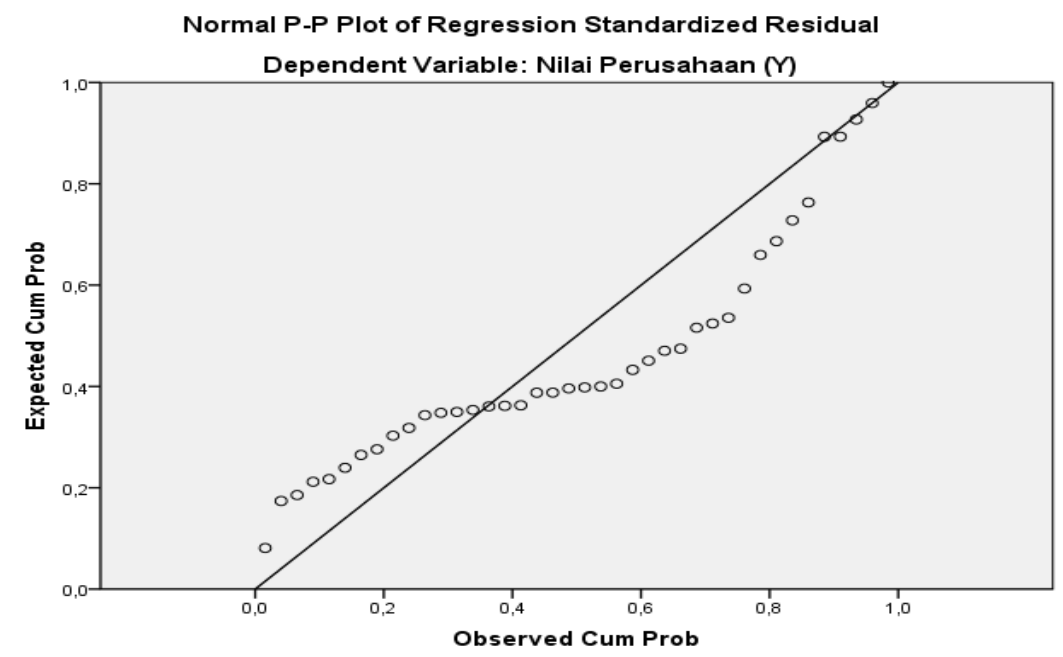

Fig. 1. The Result of Normalcy Model Assumptions

Table 6. Multicollinearity Test Results

\begin{tabular}{cllrl}
\hline No. & & Variable & VIF & \multicolumn{1}{c}{ Conclusion } \\
\hline 1 & Stock Price $(X 1)$ & Investment Decision $(Z)$ & 2.129 & No Multicollinearity \\
2 & Stock Trading Volume $(X 2)$ & Investment Decision $(Z)$ & 1.145 & No Multicollinearity \\
3 & PBV $(X 3)$ & Investment Decision $(Z)$ & 2.051 & No Multicollinearity \\
4 & DER $(X 4)$ & Investment Decision $(Z)$ & 1.191 & No Multicollinearity \\
5 & Stock Price $(X 1)$ & Company Value $(Y)$ & 1.238 & No Multicollinearity \\
6 & Stock Trading Volume $(X 2)$ & Company Value $(Y)$ & 2.076 & No Multicollinearity \\
7 & PBV $(X 3)$ & Company Value $(Y)$ & 1.191 & No Multicollinearity \\
8 & DER $(X 4)$ & Company Value $(Y)$ & 1.085 & No Multicollinearity \\
9 & Investment Decision $(Z)$ & Company Value $(Y)$ & 1.238 & No Multicollinearity \\
\hline
\end{tabular}

Source: Processed Data

2) Heteroscedasticity Test

Heteroscedasticity Test is conducted through a scatter plot graphic test, and in the test result there is no clear pattern, and there is a point spreading wide above and below zero on the $Y$ axis. It means that there is no heteroscedasticity among the variables of this study.

The basis for decision making among others are:

1. If there is a pattern like dots (points), which form a certain regular pattern (wavy, widened and then narrowed), then there is a heteroscedasticity. 
2. If there is no clear pattern, as well as the points spread above and below zero on the $\mathrm{Y}$ axis, then there is no heteroscedasticity.

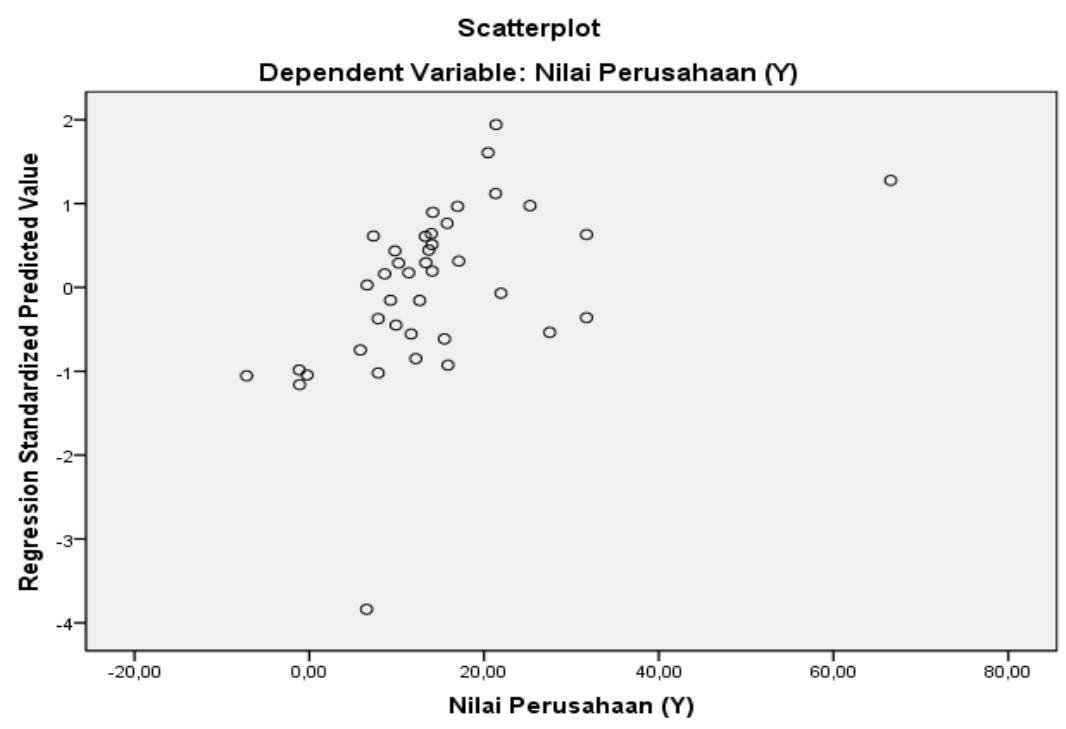

Fig. 2. Scatter Plot

The graphic shows that the data distribution does not form a specific line, or in other words it distributes in random. This means that the independent variable does not form a heteroscedasticity.

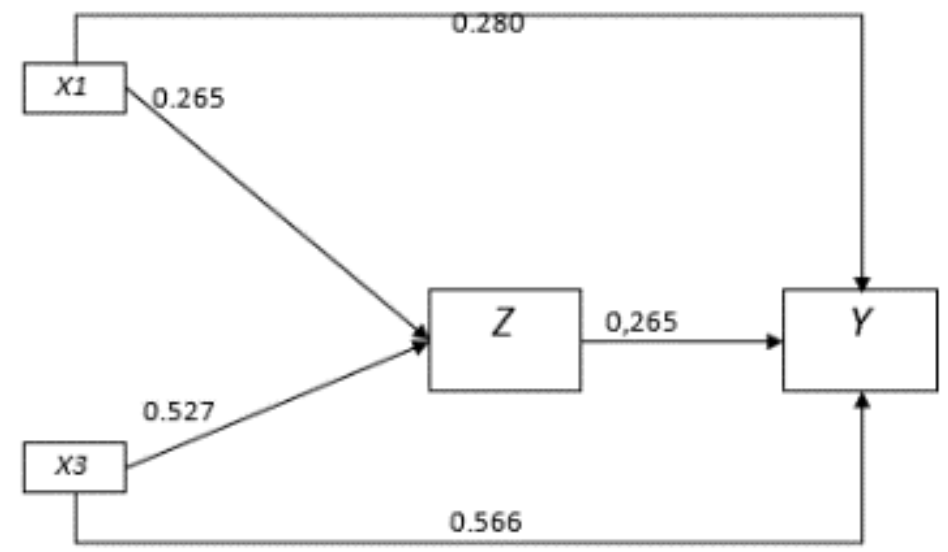

Fig. 3. Path Analysis Model

According to figure 3 (the path analysis model), the direct or indirect influences of the stock price factor, and the influences of the PBV to the company value $(Y)$ can be calculated. Table 7 displays the effect intensity based on the cross coefficient calculation of each variable.

Based on the calculation of cross coefficients in Table 7, it appears that the total influence of the stock price $(X 1)$ factor toward the investment decision is $26.5 \%$, which is a direct influence, and the total influence of the PBV (X3) toward the investment decision is $52.7 \%$, which is also a direct influence. Meanwhile, the investment decision variable has a direct influence on the total company value $(Y)$ of $26.5 \%$, and the total influence of the Stock Price variable $(X 1)$ to the company value $(Y)$ of $28 \%$. Next, the total influence of the PBV variable $(X 3)$ to the firm value 
$(Y)$ is $56.6 \%$. Thus, the hypothesis stating that the stock price and the PBV factor have positive effects on the company value, especially for companies in agricultural sector, is proven or accepted. Meanwhile, the other variables, according to theorema trimming, are proven to be unable to be included in the path calculation if the path is proven to be insignificant, in this case the DER variable and trading volume variable.

Table 7. The Calculation of Direct, Indirect, and Total Influences

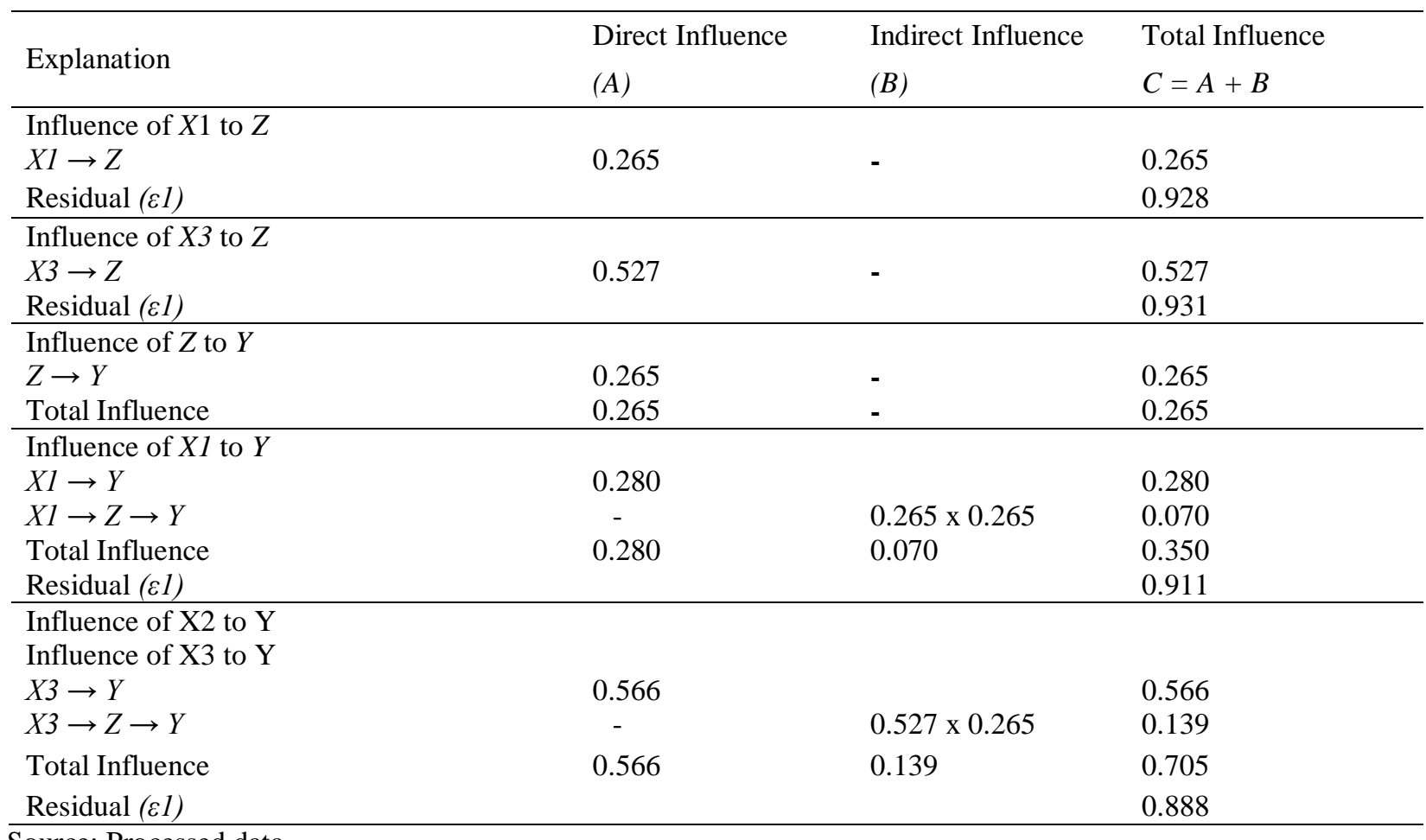

Source: Processed data

The analysis result showed that any reduction on the stock price growth rate by one percent Rupiah will increase the growth rate of the investment decision and the company value. The positive relationship direction between the stock price variable and the investment decision variable shows that the higher the stock price will lead to higher investment decision. This relationship direction is in accordance with the expected relationship direction in the hypothesis. This study is not consistent with the findings of several previous studies because of differences in the research object, the time of the research, and the variable measurement used. This study is also consistent with Putra (2005), whose research concluded that the stock price, the trading volume, and the PER have influences on the investment decision.

The trading volume does not significantly influence the investment decision. This suggests that any increase in the stock trading will not necessarily raise the growth rate of the investment decisions. Thus, the stock trading volume variable does not affect the investment decision-making. The relationship direction of the result is consistent with the expected relationship direction in the hypothesis. Thus, the result of this study is also consistent with Nurrahman (2004) who researched about the effect of stock price, trading volume, and growth rate on the investment decision, concluded that the stock price, the trading volume, and the growth rate variable have significant influences on the investment decision. This research is not consistent with several previous studies because of differences in the research object, the research time, and the research variable measurement used.

The DER does not have a significant effect on the investment decision. This means that any increase in the growth rate of the DER by $1 \%$ will not increase the investment decision. Despite the fact that the DER variable is not significant, it has a positive sign to the investment decision. The implication is that in spite of the higher DER, the companies tend to improve the use of debt even further. In other words, even though the sample companies in this 
study have a high DER, their use of debt is also high. It is because of the high level of debt as the result of fluctuations in IDR exchange rate against USD, which sharply raise the corporate debt. Another explanation is that the companies increased the debt by not paying attention to their DER, as long as the creditors still put trust on the companies, and provide loans. The test result in this study is not consistent with a previous study conducted by Sofiati (2001). In her study concerning the effect of interplay between the debt and the equity on the investment decision of go-public companies in the Jakarta Stock Exchange (JSX), she concluded that the stock price significantly influences the investment decision and the debt positively affects the equity. However, this positive coefficient is insignificant and it indicates that the company's growth does not relate to the company's investment decision-making. In addition, this research is also not in line with Ravid (2009), who states that the DER has a positive effect on the debt. That is because of differences in the research object, the research time, and the research variable measurement used.

The company value significantly influences the investment decision. This means that any 1 million rise in the growth rate of the company value will increase the investment decision. The positive relationship direction in the result is in line with the expected relationship in the hypothesis. This finding means that a larger company in agricultural sector in BEI will have an investment decision with a greater proportion of debt. The investment decision policy with a funding proportion from a larger debt can cause a higher financial risk. It means that companies in agricultural sector in the BEI is very vulnerable to monetary crisis affecting the financial distress. The result of this study is supportive and consistent with the Pecking Order Theory by Myers (1984). This theory is based on the asymmetric information and explains that when a company conducts financing by issuing new shares, it will cause the earnings per share to fall because the number of shares will increase and the company will not take advantages on the CR income from the debts. Therefore, the Pecking Order Theory describes that the funding sequence should come from the retained earnings as the first alternative, the debt as the second alternative, and the new share issuance of as the last alternative. The result of this study is also consistent with a previous study conducted by Putra (2005). In his study, he analyzes factors that influence the investment decision in manufacturing Industries. It is also consistent with Wahidahwati (2002) who stated that the company has a significant influence on the company investment decision ratio. However, this study is not consistent with Ariyanto (2002) who stated that the company value has a negative effect on the company investment decision.

\section{Conclusions}

The research result shows that the stock price is a technical factor that significantly influences the investment decision and the company value. Meanwhile, a fundamental factor that influences the investment decision and the company value is the PBV. The hypothesis stating that the stock price and the PBV have positive influences on the company value in the agricultural sector is proven or accepted. The other variables, corresponding to theorema trimming, are proven to be unable to be included in the path calculation if the path is proven to be insignificant, in this case the DER and trading volume variables.

Suggestions that can be proposed in this research are:

a. Companies need to be careful in creating an investment decision. Investment decisions should be based on the result of technical and fundamental analysis that can be taken into consideration for investors in deciding a profitable investment.

b. It is admitted that this research still needs to be improved and followed up by further researches. In order to achieve a better result than the previous studies, further researchers and academia are expected to pay attention on some following details:

1. The research variables should be added with other study variables that may influence the investment decision (e.g. macro variables such as the exchange rate, the inflation, etc.).

2. The research time should be extended in order to obtain an accurate research results for a long term.

3. The research population needs to be extended by including industries from various backgrounds or adding more variables to gain a better result. Population that is extended by adding other industry sectors will produce a more generalizable result that can be applied to other research objects. 


\section{References}

Afiruddin Tapa dan Maziah Hussin 2016. The Relationship between Stock Return and Trading Volume in Malaysian ACE Market. International Journal of Economics and Financial Issues. 6(75), 141-152.

Ariska, M., Fahru, M., \& Kusuma, J. W. (2020). Leverage , Ukuran Perusahaan dan Profitabilitas dan Pengaruhnya Terhadap Tax Avoidance Pada Perusahaan Sektor Pertambangan di Bursa Efek Indonesia Tahun 2014-2019 Leverage, Ukuran Perusahaan dan Profitabilitas dan Pengaruhnya Terhadap Tax Avoidance Pada. Jurnal Revenue : Jurnal Ilmiah Akuntansi, 01(01), 133-142.

Ende, E., \& Kusuma, J. W. (2017). Peran Citra Merek, Persepsi Harga, Persepsi Risiko Terhadap Minat Beli Produk Smartphone Merek Xiaomi. Sains: Jurnal Manajemen Dan Bisnis, 9(2), 349-365. https://doi.org/10.35448/jmb.v9i2.4169

Kusuma, J. W., Jefri, U., Hidayat, A., \& Hamidah, H. (2020). Application of Treffinger Learning Model to Improve Creative Reasoning and Mathematical Problem Solving Skills as Well as Student Learning Interests. JTAM (Jurnal Teori Dan Aplikasi Matematika), 4(2), 204. https://doi.org/10.31764/jtam.v4i2.2840

Ahmad, Gatot Nazir dan Siahaan, Mega Elvinda. 2016. Analysis of Financing Decision, Investment Decision, Dividend Policy And Value of The Firm That Listed On Kompas 100 Index. Faculty of Economics, State University of Jakarta.

Ali Ahmadi. 2018. The Stock Price Valuation of Earnings Per Share and Book Value: Evidence From Tunisian Firms. International Journal of Economics and Financial Issues, 6(S7) 271-278.

Baresa, Suzana; Bogdan, Sinisa; Ivanovic, Zoran 2016. Capital investments and financial profitability, UTMS Journal of Economics, ISSN 1857-6982, University of Tourism and Management, Skopje, Vol. 7, Iss. 1, pp. 49-59

Boumosleh, Anwar 2012. Firm Investment Decisions, Dividend Policy, And Director Stock Options. The Journal of Applied Business Research - July/August 2012 Volume 28, Number 4. Page 750-768

Chen, S. J. Son-Nan Chang dan William T. Moore. 2014. The effect of uncertain inflation on firm value in a multiperiod economy. Review of Quantitative Finance and Accounting. March 1, Volume 4, Issue 1, pp 47-58

Cheung, William Mingyan, Richard Chung dan ScottFung. 2015. The Effects Of Stock Liquidity On firm Value and Corporate Governance: Endogeneity and The REIT experiment. Journal Coorparate Finance. Pg. 231-232

Djamaluddin, Said, Maryadi dan Bambang Marsoem. 2018. The Effect of the Fundamental Faktors Against Price to Book Value on Building Construction Sub-Sector Companies in Indonesia Stock Exchange 2012-2016

Drakopoulou Veliota, 2015. A Review of Fundamental and Technical Stock Analysis Techniques. J Stock Forex Trad. ISSN: 2168-9458 JSFT, Volume 5 No.1.

Farooq, Muhammad Azhar dan Masood, Ahsan. 2016. Impact of Financial Leverage on Value of Firms: Evidence from Cement Sector of Pakistan. Research Journal of Finance and Accounting Vol.7, No.9, Page 73-77

Hajering 2018. The Influence of Investment Decisions, Funding Decisions and Dividend Policies On Financial Performance And The Value Of Banking Companies Listed In Indonesia Stock Exchange. International Journal of Business and Management Invention (IJBMI)ISSN (Online): 2319 - 8028, ISSN (Print): 2319 801Xwww.ijbmi.org || Volume 7 Issue 10 Ver. 1 || October 2018 || PP-63-71

Jeleel, Abdul dan Olayiwola, Badmus. 2017. Effect of Leverage on Firm Performance in Nigeria: A Case of Listed Chemicals and Paints Firms in Nigeria. Journal of Internet Banking and Commerce. Volume 2. Page. 121Isuue 1 ISSN: 1204-5357

Kasmir, 2008. Bank dan Lembaga Keuangan Lainnya. Edisi Revisi 2008. Jakarta: PT. RAJAGRAFINDO PERSADA Martono dan, Harjito, Agus. 2013 Manajemen Keuangan,edisi1.yogyakarta: EKONISIA

Masry, Mohamed. 2017. The Impact of Technical Analysis on Stock Returns in an Emerging Capital Markets 
(ECM's) Country: Theoretical and Empirical Study International Journal of Economics and Finance; Vol. 9, No. 3.

Muhammad, Shakeel dan Ali, Gohar.2018. The Relationship Between Fundamental Analysis and Stock Returns Based on the Panel Data Analysis; Evidence from Karachi Stock exchange (KSE). Research Journal of Finance and Accounting. Vol.9, No.3.Page. 84-96

Murniati, Sitti. Abdul Rahman Mus, Baharuddin Semmaila dan A. Nirwana Nur. 2019. Effect of Investment Decisions, Financing Decisions and Dividend Policy on Profitability and Value of The Firm. International Journal of Accounting \& Finance in Asia Pasific (IJAFAP) Vol. 2 No. 1, Page 110-121

Petrusheva, Nada dan Jordanoski, Igor.2016. Comparative Analysis Between The Fundamental And Technical Analysis Of Stocks. Journal of Process Management - New Technologies, International Vol. 4, No.2

Ramadan Imad Zeyad R. 2015, Leverage and the Jordanian Firms' Value: Empirical Evidence. International Journal of Economics and Finance; Vol. 7, No. 4.73-80

Suresh. A.S,.2013. A Study on Fundamental and Technical Analysis. International Journal of Marketing, Financial Services \& Management Research ISSN 2277- 3622 Vol.2, No. 5.page 44-59

Sutrisno. 2012. Manajemen Keuangan Teori, Konsep dan Aplikasi. Yogyakarta: EKONISIA.

Tapa, Afiruddin dan Hussin, Maziah. 2016, The Relationship between Stock Return and Trading Volume in Malaysian ACE Market. International Journal of Economics and Financial Issues, 6(S7) 271-278

Wang, Yun-Chin Jean Yu dan Shiow-Ying Wen. 2014.Does Fundamental and Technical Analysis Reduce Investment Risk for Growth Stock? An Analysis of Taiwan Stock Market 